\title{
Getting Engaged: Program and Event Planning for Clients with Diverse Abilities ${ }^{1}$
}

\author{
Kathryn Stofer ${ }^{2}$
}

\section{Overview}

This publication will aid Extension professionals and others who plan programs and events in accommodating and widely advertising accommodation availability for prospective attendees. We often add accommodation as an afterthought, placing additional burdens on populations already disadvantaged in comparison to their peers. Therefore, this guide aims to help professionals incorporate accommodation from the beginning of planning. This is one of several documents in a series Getting Engaged (http://edis.ifas.ufl. edu/topic_series_getting_engaged), which aims to help researchers and others interested in public engagement.

\section{Introduction}

As event planners, we may overlook people with diverse physical or mental abilities or chronic illnesses, even if the programs and events are accessible to a wide variety of audiences. This oversight may be especially frequent in the case of people with hidden conditions who may appear healthy. As an equal opportunity institution, the University of Florida offers a Disability Resource Center that aims to help students in courses who need various accommodations due to physical capabilities, learning styles, and chronic illness succeed in their academic careers. These resources offer faculty and students best practice guidelines for negotiating needs. While these are a good set of resources to begin program planning with, they may not directly apply to other programs hosted by the University, including Extension programs and other public events.

\section{Why is it a problem not to provide or advertise accommodations?}

"By failing to provide access information, organizers are implicitly communicating to disabled and chronically ill [people] that they haven't thought about access issues relating to the organization of their [event], and further, that they don't really think about disabled or chronically ill [people] as being part of the ... community likely to attend" (PhDisabled, 2014).

By placing people who may need accommodation at the forefront of event planning, you reduce an additional burden on those seeking accommodation. Doing so also prevents those seeking accommodation from having to share their needs; forcing people to ask for accommodation and disclose their disability may even be illegal under the Americans with Disabilities Act (ADA). Additionally, you are asking people to present and identify themselves as someone with a disability first, rather than presenting and identifying primarily as someone interested in attending your program and contributing to your event.

Accessibility is not an either/or; it is more nuanced, and some areas and programming may be accessible for some people and not others (Henry, 2014).

1. This document is AEC636, one of a series of the Agricultural Education and Communication Department, UF/IFAS Extension. Original publication date March 2018. Visit the EDIS website at http://edis.ifas.ufl.edu.

2. Kathryn Stofer, research assistant professor, Department of Agricultural Education and Communication, UF/IFAS Extension, Gainesville, FL 32611.

The Institute of Food and Agricultural Sciences (IFAS) is an Equal Opportunity Institution authorized to provide research, educational information and other services

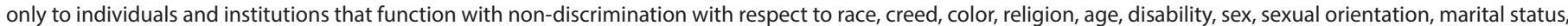

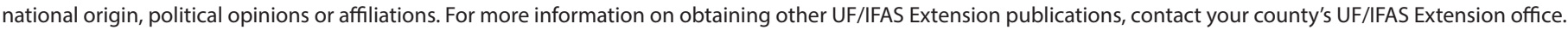
U.S. Department of Agriculture, UF/IFAS Extension Service, University of Florida, IFAS, Florida A \& M University Cooperative Extension Program, and Boards of County Commissioners Cooperating. Nick T. Place, dean for UF/IFAS Extension. 


\section{How to Include Accommodations in Your Event Planning}

Here are steps you can take to remove these burdens and advertise the accommodations you are already making:

\section{Initial Planning}

- Location - choose locations that comply with ADA regulations as much as possible. Older buildings and smaller businesses may not have been updated with the most accessible features.

- Funding - plan up front for funding the services of a sign language interpreter, captioning, recording, and alternate access (such as live webcasts of in-person events).

- Program materials - work with presenters well ahead of time to obtain materials in different formats to accommodate people with different needs.

- Timing - host events during hours and days when public transportation is available.

- If in doubt, ask participants; do not assume what their needs may be (International Association for Geoscience Diversity, n.d.).

\section{Advertising}

- Put information about the accommodations, or lack thereof, in a prominent part of all your advertising to reduce the burden on people seeking this information. They are already dealing with their additional needs above and beyond those people who are served by "normal" accommodations; making this information visible makes it easier for them to decide whether they can attend an event they are interested in, or whether you might be able to make further accommodations they may need.

- Ensure the advertising itself is as accessible as possible.

- Advertise all of the following information publicly, or clearly state in the advertising where to find the relevant accessibility information:

- Physical access not only to the building but also to the particular room where the event will be held, with or without mobility aids such as scooters or wheelchairs, but also including the type of flooring, as carpet or uneven flooring or pavement can be harder to navigate with wheels or crutches.

- Transportation options, including physically accessible public transit, disabled parking, and mobility-aid accessible access routes from those areas

- Location of nearby physically accessible restrooms, including accessible family restrooms
- Video or other recording of the event for those with concentration difficulties or who might need to rest or leave early

- Live transcription of the event for people who might have hearing disabilities or auditory processing or concentration difficulties

- Allergen-free foods

- Scent-free spaces for those who might have scenttriggered headaches or asthma

- Microphones

- Large-print handouts

- Lighting for those who have illnesses triggered by fluorescent lighting

- Remaining potential barriers

- Information for service animal care

- Contact information specifically for accessibility issues

\section{Working with Allies}

Recruit and assist allies (people without need for accommodation) to help those who might take advantage of accommodation access the necessary information.

- When posting information about accessibility, include information for allies, such as the example provided by WisCon: http://wiscon.net/policies/accessibility/\#allies.

- Share your accessibility plans explicitly with your speakers, assistants, and other co-organizers so as many people as possible have access to share this information with those who need it.

\section{Long-term Institutional Changes}

Beyond simply planning for your own programs and events, work to make issues for accessibility known and included systematically (for example, across programs within county Extension offices), not just to be considered by a few.

- "If you receive communication about an event and no access information is given in what's been posted publicly, contact the organizer and ask them to make this information public. Especially do this if you are non-disabled." (PhDisabled, 2014).

- Share these planning steps with as many people as possible who may be able to advocate for these accommodations.

- Continue to learn about needs of people with a variety of disabilities and illnesses, so that those with the disabilities and illnesses are not further burdened with educating those without. 
- Work to share these needs with administration to better institutionalize these steps, including providing funding for accommodation services on a system-wide, rather than per-program, basis.

\section{Conclusion}

While incorporating these steps in your program planning early may take some effort in the beginning, doing so relieves further burden from participants who need the assistance. Reducing barriers to participation may lead to a broader audience for your programs. Ultimately, the time and effort invested is worth it to serve often-overlooked populations.

\section{Additional Resources}

University of Florida ADA Compliance Office contact: ADA Coordinator Ken Osfield, kosfield@ehs.ufl.edu, (352) 392-1591 or 711(TDD/TTY)

University of Florida ADA Compliance Office - Services to Persons with Disabilities web page: http://www.ehs.ufl.edu/ programs/ada/services/

Universal Design and Disability Access at WisCon (A Wisconsin-based convention on Science Fiction and Fantasy): http://wiscon.net/policies/accessibility/

Hotels and conference centers with accessibility policies: http://geekfeminism.wikia.com/wiki/List_of_Convention_Centers_and_Hotels_with_Accessibility_Policies

Considerations for accommodating people with partial sight: https://hannah-thompson.blogspot.com/2014/11/ practising-inclusive-access.html

Considerations for accommodating people with hearingrelated disabilities: https://modelviewculture.com/pieces/ qa-making-tech-events-accessible-to-the-deaf-community

Considerations for accommodating people with physical disabilities: https://modelviewculture.com/pieces/unlocking-the-invisible-elevator-accessibility-at-tech-conferences

\section{References}

International Association for Geoscience Diversity. (n.d.) Ending the Awkward. Retrieved from http://theiagd.org/ forums/topic/ending-the-awkward-ask-dont-assume/

Henry, L. (2014). Unlocking the Invis-

ible Elevator: Accessibility at Tech Conferences

Retrieved from https://modelviewculture.com/pieces/ unlocking-the-invisible-elevator-accessibility-at-techconferences.

PhDisabled. (2014). Event Organizers: Give Access Information Up Front. Please? | PhD(isabled). Retrieved from https://phdisabled.wordpress.com/2014/10/30/ event-organizers-give-access-information-up-front-please/ 